\title{
New cases of polyodontia in the dawn bat, Eonycteris spelaea (Mammalia: Chiroptera: Pteropodidae)
}

\author{
Sergey V. Kruskop
}

\begin{abstract}
While working with the Prof. Abe's collection, which is stored at the Hokkaido University (Sapporo), a specimen of the fruit bat Eonycteris spelaea (No. 56289) was discovered, possessing additional molars in all four tooth rows. Such type of polyodontia is not known for this species, and is extremely rare for Pteropodids as a whole. Also, we did not found any mention of cases where additional molars would develop simultaneously on the lower and upper jaws. Among the examined 25 specimens of Eonycteris spelaea, two cases of olygodontia (plus one, probably representing an artefact of metabolic disorders) and five cases of polyodontia were identified. For comparison, in a sample of 40 individuals of three different species of the genus Rousettus, not a single case of polyodontia was found.
\end{abstract}

How to cite this article: Kruskop S.V. 2019. New cases of polyodontia in the dawn bat, Eonycteris spelaea (Mammalia: Chiroptera: Pteropodidae) // Russian J. Theriol. Vol.18. No.2. P.107-109. doi: 10.15298/rusjtheriol.18.2.05

KEY WORDS: Eonycteris, Old World fruit bats, tooth anomaly, polyodontia.

SergeyV. Kruskop [kruskop@zmmu.msu.ru ], Zoological Museum, Moscow State University, Bolshaya Nikitskaya 2, 125009 Moscow, Russia.

\section{Новые случаи полиодонтии у пещерного крылана, Eonycteris spelaea (Mammalia: Chiroptera: Pteropodidae)}

\section{С.В. Крускоп}

РЕЗЮМЕ. При работе с коллекцией профессора Абэ, хранящейся в Университете Хоккайдо (Саппоро), обнаружен экземпляр крылана Eonycteris spelaea (№ 56289), имеющий дополнительные моляры во всех четырех зубных рядах. Для этого вида подобный тип полиодонтии не известен и крайне редок для крыланов в целом. При этом мы не нашли упоминания случаев, когда дополнительные моляры развивались бы одновременно и на нижней, и на верхней челюстях. Среди просмотренных 25 экземпляров Eonycteris spelaea удалось выявить два случая олигодонтии (плюс один, вероятно, представляющий собой артефакт нарушения обмена) и пять случаев полиодонтии. Для сравнения, в выборке из 40 особей трех разных видов рода Rousettus ни одного случая полиодонтии обнаружить не удалось.

КЛЮЧЕВЫЕ СЛОВА: Eonycteris, крыланы, зубные аномалии, полиодонтия.

\section{Introduction}

Molecular methods are currently playing a leading role in taxonomic research, and bats (Mammalia: Chiroptera) are not an exception. However, far from all taxa there is an opportunity to obtain adequate genetic data, and for paleontological materials this is in principle impossible. This circumstance supports the importance of morphological studies. In particular, cases of various dental abnormalities that demonstrate the potential pathways and methods of evolution of the dental system are of great importance (Lanza et al., 2008).

While working with Prof. Abe's collection at the Museum of the Botanical Garden of Hokkaido University (Sapporo, Japan), a skull of Eonycteris spelaea (Dobson, 1871 ) with a tooth abnormality was found. This skull No. 56289 belongs to an adult male and represents a part of small series of specimens (five) collected in a Mae Hong Son Province, north-western Thailand. All the animals were originally labeled as Rousettus leschenaultii (Desmarest, 1820) however we reidentified four specimens as E. spelaea based on their morphological peculiarities (see Kruskop, 2013). Discussing specimen has skull measurements common for the species (in $\mathrm{mm}$ ): condylo-basal length 32.81, condylo-canine length 31.09, upper tooth row length 12.50 , lower tooth row length 14.08 , canine width 7.10 , zygomatic width 15.51 , postorbital width (behind supraorbital processes) 7.29, brain case width 12.55. Animal has six upper cheek teeth (three premolars and three molars) and seven lower cheek teeth (three premolars and four molars) symmetrically in each side (Fig. 1). Common tooth formula for Eonycteris (and other rousettines) is: 

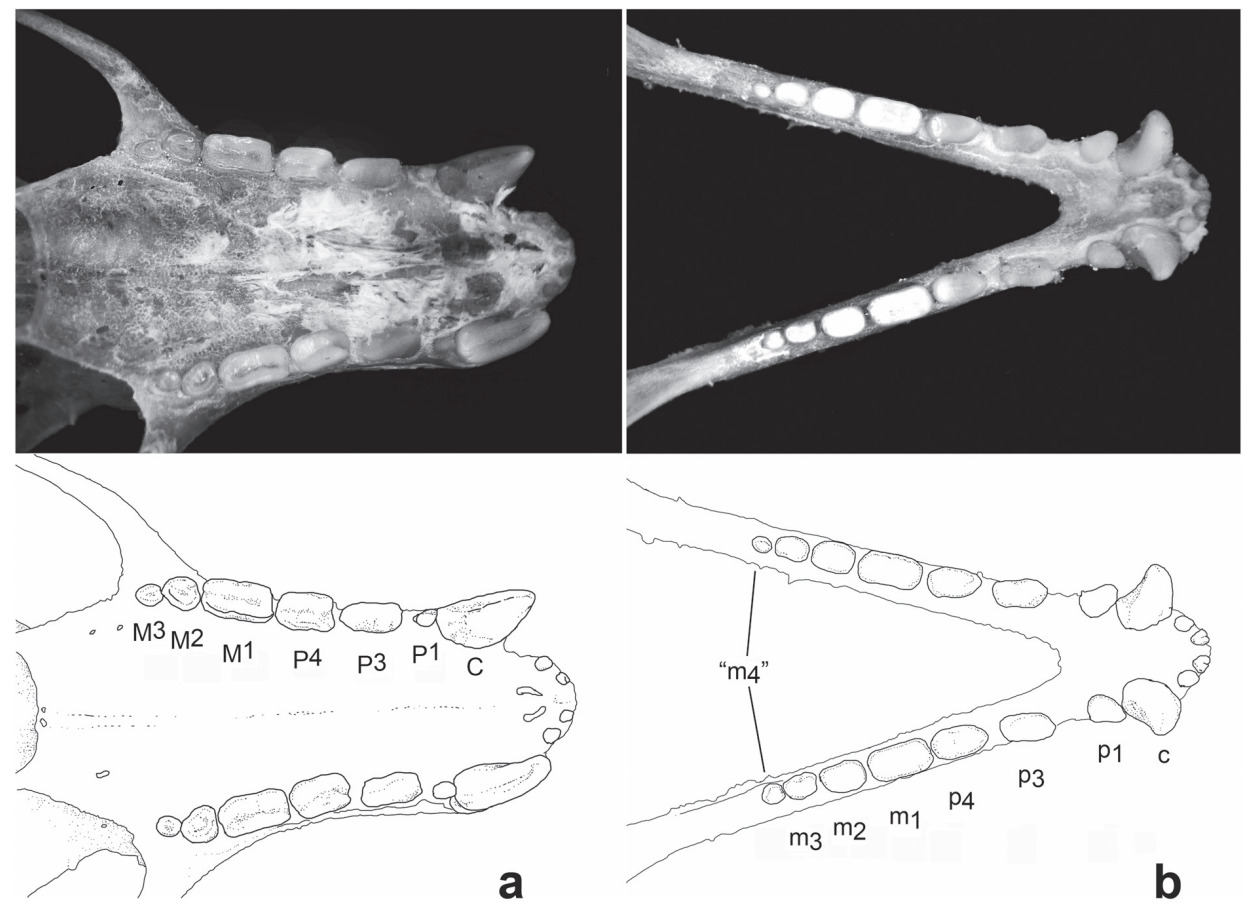

Fig. 1. Photography and outline explanation of abnormal tooth rows in Eonycteris spelaea (Abe's collection, No. 56289): $\mathrm{a}$ - upper teeth, $\mathrm{b}$ - lower teeth. Extra teeth are $\mathrm{M}^{3}$ and " $\mathrm{m}_{4}$ ".

$$
\frac{\mathrm{I}^{1} \mathrm{I}^{2} \mathrm{CP} \mathrm{P}^{1} \mathrm{P}^{3} \mathrm{P}^{4} \mathrm{M}^{1} \mathrm{M}^{2}}{\mathrm{i}_{1} \mathrm{i}_{2} \mathrm{cp}_{1} \mathrm{p}_{3} \mathrm{p}_{4} \mathrm{~m}_{1} \mathrm{~m}_{2}\left(\mathrm{~m}_{3}\right)} \times 2=34(32)
$$

Apart from fluctuations of the last molar, this formula is close to the most basal for Pteropodidae (Andersen, 1912; Koopman, 1994). Thus, the presence of additional molars in both upper and lower tooth rows is not the norm for Eonycteris (and it is not known in other pteropodids). But, if the third upper molars are present in other groups of mammals, including other bat families (Koopman, 1994), and theoretically can be considered as atavism, then the presence of the fourth lower molars is an undoubted anomaly. Similar anomalies are described in Epomophorus wahlbergi (Sundeval, 1846) in the upper jaw (Lanza et al., 2008) and in Nyctimene albiventer (Gray, 1863) in the lower (Giannini \& Simmons, 2007). However, since both species normally have a reduced number of molars, even in the case of an anomaly, it does not exceed the usual for pteropodids. Homologizing molars of the Old World fruit bats is difficult, since they are greatly simplified and practically devoid of characteristic features (Koopman \& MacIntyre, 1980). However, in the specimen under discussion, the upper last molars, although smaller than the previous ones, are similar in shape to them (and significantly differ from $\mathrm{M}^{1}$ ). It can be assumed that it was the rear molars that were duplicated. In the lower jaw, the molars change gradually from the large and elongated anterior to the small rounded posterior (additional), complicating any assumptions about homology.
We checked available material for E. spelaea in Zoological Museum of Moscow University (ZMMU) from Vietnam and Cambodia (in total, together with the Thailand specimens from Prof. Abe's collection, 25 individuals) and found unpredictably high level of tooth anomalies. In one case (female ZMMU S-165023) left $\mathrm{m}_{3}$ is absent, which is supposed to be relatively common case for Eonycteris (Andersen, 1912). In ZMMU S-191901 (male) anterior molars are absent on both sides of the upper jaw. In ZMMU S-175746 (female) first and second molars are absent on both jaws. However, in this case, this may be the result of illness and metabolic disorders, since this individual was obtained from captivity. In one case (ZMMU S-165024, male) we found additional incisor (probably as result of duplication of left $\mathrm{I}^{2}$ ). In ZMMU S-191900 (male) " $p_{2}$ " (i.e. additional small premolars between $p_{1}$ and $p_{3}$ ) are developed symmetrically (Fig. 2). In two specimens, ZMMU S-167148 (female) and ZMMU S-172230 (male), we found additional posterior molars, upper left and lower left, respectively. Thus, if we exclude the doubtful case of the animal from captivity, we found dental abnormalities in seven out of 25 individuals examined, including five cases of polyodontia ( $20 \%$ of the material viewed). It is believed that anomalies associated with incisors or premolars are more common in pteropodids than molar anomalies (Giannini \& Simmons, 2007; Lanza et al., 2008). However, in our case, it is the latter that obviously prevail. In most revealed cases of asymmetric anomalies, they are located on the left side. The uniqueness of the specimen from the Prof. Abe's collection is that additional teeth are formed symmetrically in both jaws. 


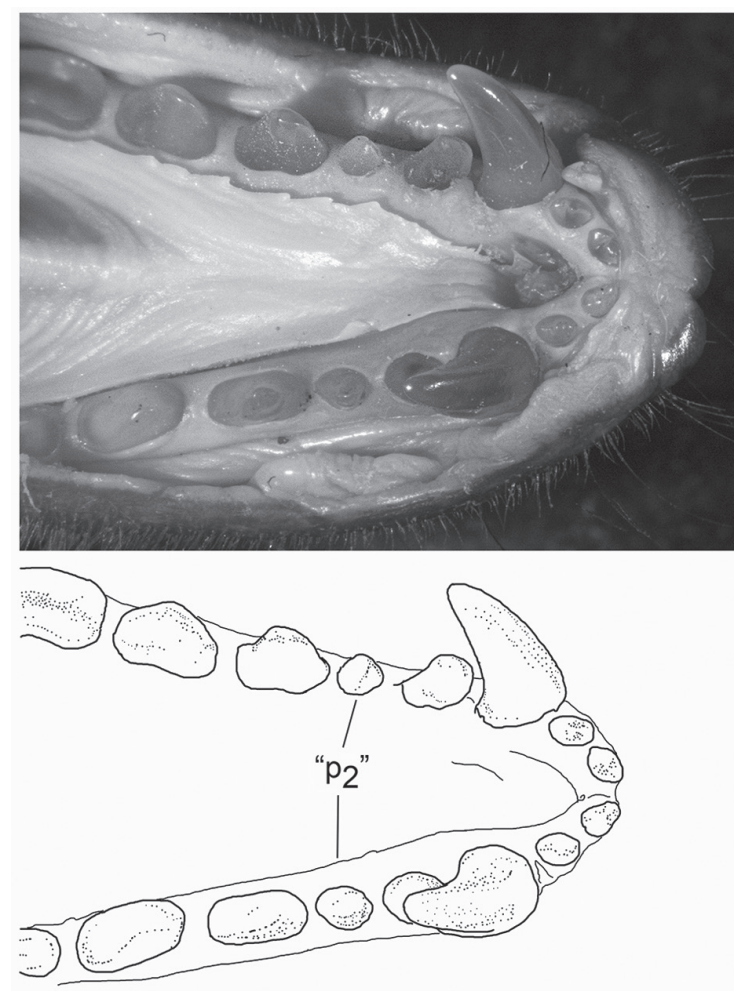

Fig. 2. Anterior lower teeth of the specimen ZMMU S-191900 with well-seen additional premolars (" $\mathrm{p}_{2}$ ").

We also examined five specimens of $R$. leschenaulti and same number of Rousettus amplexicaudatus (E. Geoffroy, 1810) from various regions of tropical Asia, and 30 specimens of $R$. aegyptiacus (E. Geoffroy, 1810) from Guinea and Ethiopia (ZMMU collection). None of the checked specimens polyodontia was not revealed (and two cases of missed teeth in R. amplexicaudatus can be attributed to injury). It can be assumed that, since Eonycteris, in contrast to the more generalized Rousettus, is adapted to nectar feeding (Freeman, 1995; Kirsch \& Lapointe, 1997), the selection pressure on its dental system and, in particular, on the number and shape of molars, is reduced.

ACKNOWLEDGEMENTS. Authors work with the Prof. Abe's collection was conducted with kind help from Dr. Kuniko Kawai (Tokai University, Japan) and Mr. Fumihito Takaya (Hokkaido University, Japan). The study was performed in line with State theme of scientific work of the ZMMU (AAAA-A16-116021660077-3) with financial support from the Russian Foundation for Basic Research (grant No. 17-04-00689a).

\section{References}

Andersen K. 1912. Catalogue of the Chiroptera in the Collection of the British Museum. 2nd ed. Vol.1: Megachiroptera. London: British Museum (Natural History). 854 p.
Freeman P.W. 1995. Nectarivorous feeding mechanisms in bats // Biological Journal of the Linnean Society. Vol.56. No.3. P.439-463.

Giannini N.P. \& Simmons N.B. 2007. Element homology and the evolution of dental formulae in Megachiropteran bats (Mammalia: Chiroptera: Pteropodidae) // American Museum Novitates. No.3559. P.1-27.

Kirsch J.A.W. \& Lapointe F.J. 1997. You aren't (always) what you eat: evolution of nectar-feeding among Old-World fruitbats (Megachiroptera: Pteropodidae) // Givnish T.J. \& Sitsma K.J. (eds.). Molecular Evolution and Adaptive Radiation. Cambridge: Cambridge University Press. P.313-331.

Koopman K.F. 1994. Chiroptera: systematics. Handbook of Zoology. Vol.8: Mammalia. New York: Walter de Gruyter. $217 \mathrm{p}$.

Koopman K.F. \& MacIntyre G.T. 1980. Phylogenetic analysis of chiropteran dentition // Wilson D.E. \& Gardner A.L. (eds.). Proceedings Fifth International Bat Research Conference. Lubbock: Texas Tech Press. P.279-288.

Kruskop S.V. 2013. Bats of Vietnam. Checklist and an Identification Manual. 2nd ed. Biodiversity of Vietnam series. Moscow: KMK Scientific Press. 300 p.

Lanza B., Riccucci M. \& Funaioli U. 2008. An interesting case of polyodontia in Epomophorus wahlbergi, with a review of this dental anomaly in bats (Chiroptera) // Lynx, series nova. Vol.39 No.1. P.109-127. 